This journal is the official publication of Bangladesh Society of Physiologists (BSP)

Web URL: www.banglajol.info/index.php/JBSP

Abstracted /indexed in Index Copernicus, Director of Open Access Journal, HINARI Index Medicus for South East Asia Region, Google Scholar, 12OR, infobse index, Open J gate, Cite factor, Scientific indexing services

pISSN-1983-1213; e-ISSN-2219-7508

\title{
Article
}

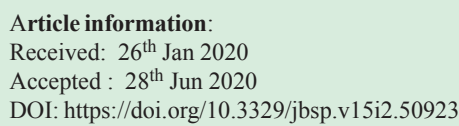

This article is open access licensed under CC BY NC SA which allows readers copy, distribute, display, and perform the work and make derivative works based on it only for noncommercial purposes.

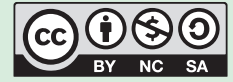

\section{Effects of green tea on glycemic status in female metabolic syndrome patients.}

\author{
Sabira Tabassum ${ }^{1}$, Qazi Shamima Akhter ${ }^{2}$ \\ 1.Department of Physiology, Delta Medical College, Dhaka. \\ 2. Department of Physiology, Dhaka Medical College, Dhaka.
}

\section{Abstract}

Background: According to International Diabetic Federation, around $20-25 \%$ of world adult population have the clinical features of metabolic syndrome (MetS). Different organizations recommend to modify lifestyle and dietary habit as primary intervention. Green tea has several pharmacological effects on metabolic diseases including MetS. Objective: To evaluate the effects of green tea consumption on two glycemic variables in women with MetS. Method: This interventional study was conducted in the Department of Physiology, Dhaka Medical College from January 2016 to December 2016. After fulfilling the ethical aspect, a total number of 42 female patients with MetS aged 40 to 50 years were selected from the outpatient department of Endocrinology, Dhaka Medical College Hospital. Participants were randomly assigned in study group $(\mathrm{n}=22)$ and control group $(\mathrm{n}=20)$. Study group consumed green tea for 12 weeks and the control group did not consume green tea. In both groups fasting serum glucose (FSG) and glycosylated hemoglobin (HbA1c) were measured by glucose oxidase (GOD/ PAP) method and modified high performance liquid chromatography (HPLC) method respectively 2 times (before and after 12 weeks). Data were analyzed by paired Student's ' $t$ ' test and unpaired Student's ' $t$ ' test. Results: After 12 weeks of intervention, FSG \& HbA1c significantly $(p<0.001)$ decreased in the study group than those of their baseline value and these values were also significantly $(p<0.05)$ lower in comparison to those of control group. Conclusions: Regular consumption of green tea may improve glycemic status in patients with metabolic syndrome.

Key words: Metabolic syndrome, green tea, polyphenol, glycemic status. 
Introduction

$\mathbf{M}$ etabolic syndrome (MetS) is a complex of interrelated risk factors that include hyperglycemia, raised blood pressure, elevated triglyceride level, low high density lipoprotein cholesterol level and obesity. ${ }^{1}$

It is becoming the major public health problem as individual with MetS has threefold risk to have heart attack or stroke and twice likely die from the complication of CVD. Moreover, people with MetS has fivefold high risk of development of type 2 diabetes. This high incidence would be added to 230 million people who already have type 2 diabetes. $^{2}$

In the recent era, diet based therapy became very much popular around the globe. Several studies also have recommended dietary regimen to prevent life threatening disorders including MetS..$^{3-4}$ Several previous studies provided the evidence of various pharmacological effects of green tea which is rich in caffeine, antioxidant and other essential nutrients. The most abundant antioxidant, the polyphenols are rich in catechins and the major catechins present in green tea are, epigallocatechingallate (EGCG), epicatechingallate (ECG) and gallocatechingallate (GCG). Among them, the EGCG shows the strongest bioactivity. ${ }^{5}$

Although a number of studies on human and animal had shown the significant effect of green tea to decrease FSG level ${ }^{6-11}, \mathrm{HbA1}_{\mathrm{C}}{ }^{12-13}$ and increase insulin sensitivity ${ }^{14-15,4}$ but some studies did not find significant changes. ${ }^{16-17}$ In Bangladesh, very few published data are available despite high rise of MeS female patients. Therefore, the present study has been designed to evaluate the effect of green tea on glycemic status by investigating $\mathrm{FSG}$ and $\mathrm{HbAl}_{\mathrm{C}}$ levels in female patients with metabolic syndrome.

\section{Methods}

This prospective interventional study was conducted in the Department of Physiology,
Dhaka Medical College, Dhaka from January 2016 to December 2016. At the beginning of the study, 48 female subject with MetS with aged 40 to 55 were selected by purposive sampling from outpatient department of Endocrinology, Dhaka Medical College Hospital. The inclusion criteria were based on modified National Cholesterol Education Program-Adult Treatment Panel (NECP ATP-III). ${ }^{18}$ These criteria included abdominal obesity (waist circumference $>80$ $\mathrm{cm}$ ), Hypertriglyceridemia ( $\mathrm{TG}>150 \mathrm{mg} / \mathrm{dl}$ ), Low HDL cholesterol (HDL-C $<50 \mathrm{mg} / \mathrm{dl}$ ), High blood pressure $>130 / 85 \mathrm{~mm}$ of $\mathrm{Hg}$ or taking antihypertensive drugs and Impaired fasting blood glucose $>5.6 \mathrm{mmol} / \mathrm{L}$. Participants who were pregnant or lactating mother, on insulin therapy, had renal or cardiac diseases, suffering from acute infection or malignancy were excluded from the study. Then the nature, purpose and benefit of the study was explained to each subject in details. Informed written consent was taken from each of the participant. Detailed history of food habit, drug intake, physical activity and diseases were taken. Among them, study group $(n=26)$ consumed green tea 1 cup thrice daily for 12 weeks and control group $(n=22)$ did not consume green tea. Anthropometric measurements (Height and weight) of the subjects were used to calculate BMI. Blood pressure was measured. FSG and $\mathrm{HbA1} \mathrm{c}$ were estimated by Cobas c-311 analyzer (Roche) These parameters were measured for both groups, at the beginning of the study (baseline) and after 12 weeks. Green tea was supplied to the study group and asked to drink one cup/three times daily 30 minutes after a meal for 12 consecutive weeks. The subjects were asked to maintain former food habit, physical activities and type and doses of medicine (oral hypoglycemic drugs, antihypertensive or lipid lowering agent) during the course of the study. Regular telephonic contact and periodic visit had made to keep contact and to supply green tea and to ensure compliance with intervention. The green tea used for intervention was manufactured 
by KAZI \& KAZI tea estate limited which has been selected by random sampling among the green tea available in the market. The participants were instructed to prepare a cup of green tea by dipping one tea bag of green tea in $150 \mathrm{ml}$ of hot water and allowed to infuse for 3 minutes. ${ }^{16}$

All data were expressed as mean $\pm \mathrm{SD}$. For statistical analysis, paired Student's ' $t$ ' test and unpaired Student's ' $t$ ' test were performed as applicable using SPSS version 22.0. In the interpretation of result, $\mathrm{p}$ value $<0.05$ was considered as level of significant.

Results

During the course of the study period, four from study group and two from control group were withdrawn due to different causes. So, finally, 22 subjects from study group and 20 subjects from control group had completed the study and data from these participants were used for analysis.

Baseline characteristics of all subjects are presented in Table I and there was no significant difference between study and control group. The baseline values of mean $\mathrm{FSG}$ and $\mathrm{HbAl}_{\mathrm{C}}$ of both groups showed no statistically significant difference. In addition, both values showed no significant difference at baseline and after 12 weeks in control group. But after 12 weeks of intervention, both FSG and HbA1c levels were found significantly decreased $(\mathrm{p}<0.001)$ in study group in comparison to baseline value. These values were also significantly lower $(\mathrm{p}<0.05)$ after 12 weeks of intervention in comparison to control group (Table II).

Table I: General characteristics of the subjects in both groups $(\mathrm{N}=42)$

\begin{tabular}{lccc}
\hline Variables & Study $(\mathrm{n}=22)$ & Control $(\mathrm{n}=20)$ & $P$ value \\
\hline Age $($ year $)$ & $48.81 \pm 4.76$ & $47.80 \pm 4.33$ & 0.475 \\
BMI $\left(\mathrm{Kg} / \mathrm{m}^{2}\right)$ & $32.22 \pm 2.14$ & $31.62 \pm 1.80$ & 0.629 \\
Systolic BP $(\mathrm{mm}$ of $\mathrm{Hg})$ & $122.72 \pm 6.85$ & $128.40 \pm 14.87$ & 0.115 \\
Diastolic BP $(\mathrm{mm}$ of $\mathrm{Hg})$ & $83.86 \pm 6.53$ & $79.75 \pm 6.97$ & 0.055 \\
\hline
\end{tabular}

Data were expressed as mean $\pm \mathrm{SD}$. Unpaired student's ' $\mathrm{t}$ ' test was used. $p$ value $<0.05$ was accepted as level of significance. $\mathrm{N}=$ Total number of subjects, $\mathrm{n}=$ number of subjects in each group, BMIBody mass index.

Table II: Fasting blood glucose (FBG) and HbA1c levels in different groups $(\mathrm{N}=42)$

\begin{tabular}{lccccc}
\hline Variables & \multicolumn{2}{c}{ Study $(\mathrm{n}=22)$} & & \multicolumn{2}{c}{ Control(n=20) } \\
\cline { 2 - 3 } & Baseline & After 12 weeks & & Baseline & After 12 weeks \\
\hline FBG $(\mathrm{mmol} / \mathrm{L})$ & $8.67 \pm 1.22$ & $7.58 \pm 1.20^{* * *}$ & & $8.50 \pm 1.42$ & $8.58 \pm 1.44^{\mathrm{ns}}$ \\
HbA1c $(\%)$ & $6.45 \pm 1.16$ & $5.95 \pm 1.08^{* * *}$ & & $6.61 \pm 1.13$ & $6.63 \pm 1.15$ \\
\hline
\end{tabular}

Results were expressed as mean $\pm \mathrm{SD}$. Statistical analysis was done by Paired t test for comparison within groups and unpaired t test for comparison between the groups. $\mathrm{N}=$ Total number of subjects, $\mathrm{n}=$ number of subjects in each group, $* * *=$ MetS with green tea at baseline vs after 12 weeks; $\gamma=$ MetS with green tea vs without green tea after 12 weeks; $p$ value ${ }^{* * *} / \#^{\prime} \# 0.001, p$ value $\gamma<0.05$. ns $=$ non significant, Study-MeS patients with green tea .Control- MeS patients without green tea. 
Discussion

Among the MeS patients in this study, FSG and $\mathrm{HbA1c}$ levels were similar at baseline of the study which is similar to other studies. ${ }^{17,19}$ After consumption of green tea, the mean FSG and HbA1c significantly decreased from their baseline as well as it was found lower to the control group after 12 weeks. These findings were supported by others. ${ }^{13,19}$ On the contrary, one study found significant reduction in $\mathrm{HbA} 1 \mathrm{c}$ level with a non-significant change in FSG level and the duration of intervention was short ( 8 weeks). ${ }^{12}$ Another study found no significant difference in FSG and HbAlc level. ${ }^{20}$ Here the study group had taken green tea before a meal for 16 weeks, but sample were taken after two weeks of washout period.

Several studies have suggested that green tea catechins (EGCG \& ECG) can improve the glycemic status by several mechanisms. The mechanisms include decrease carbohydrate digestion and glucose absorption in intestine, activation of insulin receptors and increase glucose uptake in insulin-sensitive tissues. It also stimulates insulin secretion from the pancreatic $\alpha$-cell and decreases hepatic glucose output. ${ }^{21}$ Green tea polyphenols inhibit the hydrolytic effect of carbohydrate amylase \& glucosidase, thereby interfere the digestion of complex carbohydrate into glucose. ${ }^{22}$ It decreases the entry of glucose from intestine by blocking both SGLT1 and GLUT2 transporter. ${ }^{23}$ One study proved that, green tea at concentration of $50 \mu \mathrm{M}$ completely blocked the GLUT2 ${ }^{24}$. Besides these, consumption of carbohydrate with green tea causes malabsorption and increase their fecal excretion. ${ }^{25-28}$ Glucose uptake in peripheral tissues through insulin is mediated by a cascade of reactions that activate the enzyme phosphatidyleinositol-3 kinase (PI3K) and promote the translocation of GLUT4 on cell surface from intracellular pool. The EGCG increases the glucose uptake by activating that
PI3K signaling pathway. Green tea extract also increases the mRNA levels of GLUT4 in the muscle tissue. ${ }^{29-31}$ Moreover, EGCG stimulates pancreatic acell to secrete insulin by increasing the number and size of the cells, prevents cytokine mediated damage, reduces the number of pathological change and degeneration of histological structure of islets of Langerhans. ${ }^{32-}$ 35 EGCG also can reduce the hepatic glucose production and output by inhibiting the enzymes involved in gluconeogenesis and glycogenolysis. On the other hand, it also increases glycogenesis by increasing the expression of glycogenic enzyme glucokinase. ${ }^{36-38}$ However, the exact mechanism involved in improvement of glycemic status of metabolic syndrome by green tea polyphenols cannot be revealed from the present study as the plasma polyphenols level in green tea and the NO, ROS levels and insulin sensitivity were not assessed.

\section{Conclusions}

After analyzing the results of the study, it can be concluded that, regular consumption of green tea may improve the glycemic status in patients with metabolic syndrome. Therefore, regular intake of green tea might be a cost effective alternative choice for management of metabolic syndrome.

\section{Ethical consideration}

Ethical clearance of this study was obtained from concerned Departments, Research review committee and Ethical review committee of Dhaka Medical College, Dhaka.

\section{Conflict of interest}

The author declares no conflict of interest.

\section{Acknowledgement}

The authors acknowledge the Outpatients Department of Endocrinology and Department of Pathology, Dhaka Medical College Hospital for their kind cooperation. 


\section{References}

1. Alberti KG, Eckle RH, Grundy SM, Zimmet PZ, Cleenman J, Donoto KA, Fruchart JC, James WP, Laria CM, Smith SC. Harmonizing the metabolic syndrome: A joint scientific statement. Circulation 2009; 120: 1640-45.

2. IDF. IDF worldwide definition of the metabolic syndrome [Internet]. Belgium: International Diabetes Federation: c 2005. The IDF consensus worldwide definition of metabolic syndrome revised 2006: [cited 2016 July 2]. Available from https://www.idf.org/ webdata/docs/Mets

3. Ahmed RS, Butt MS, Sultan MT, Mushtaq Z, Ahmed S, Dewanjee S, Feol VD, Haq MZ. Preventive role of green tea catechins from obesity and related disorders especially hypercholesterolemia and hyperglycemia. J Transit Med 2015; 13: 79-88.

4. Wu AH, Spicer D, Stanczyk FZ, Tseng CC, Yang CS, Pike MC. Effect of 2 month controlled green tea intervention on lipoprotein cholesterol, glucose, and hormone levels in healthy postmenopausal women. Cancer Prev Res (phila) 2012; 5(3): 393- 402.

5. Miyoshi N, Pervin M, Suzuki T, Unno K, Isemura M, Nakamura Y. Green tea catechins for well-being and therapy: prospects and opportunities. Botanics: Target and therapy $2015 ; 5: 85-96$.

6. Polychronopoulos E, Zeimbekis A, Kastorini, CM. et al. Effects of black and green tea consumption on blood glucose levels in non-obese elderly men and women from Mediterranean Islands (MEDIS epidemiological study). Eur J Nutr 2008; 47: 10-16.

7. H. Nyambee-Silavwe and G. Williamson. Polyphenoland fiber-rich dried fruits with green tea attenuate starch-derived postpradial blood glucose and insulin: a randomized, controlled, single-blind, cross-over intervention. Br J Nutr 2016; 116 (3): 443-50.

8. Maruyama k, Iso H, Sasaki S, Fukino Y. The association between concentration of green tea and blood glucose levels. J. Clin. Biochem. Nutr 2009; 44:41-5.

9. SC Forester, Y Gu, JD. Lambert. Inhibition of starch digestion by green tea polyphenol, (-) epigallocatechin3-gallate. Mol Nutr food res 2012; 56(11):1646-54.

10. Suliburska J, Bogdanski, Szulinska M. Effects of green tea supplementation on elements, total antioxidants, lipids, and glucose values in the serum of obese patient. Biol Trace Elem Res 2012; 149(3): 315-22.
11. Zeyuan D, Bingyin T, Xiaolin X, Jinming H, Yifeng C. Efeect of Green Tea and black Tea on the blood glucose, the blood Triglycerides, and Antioxidation in Aged Rats. J Agric Food Chem 1998;46(10): 387578.

12. Fukino Y, Ikeda A, Maruyama K, Aoki N. Okubo T, Iso H . Randomized controlled trial for an effect of green tea extract powder supplementation on glucose abnormalities. Europian J Clin Nutr 2008: 62; 95360 .

13. Hsu CH, Liao YL, Lin SC, Tsai TH, Huang CJ, Chou $\mathrm{P}, \mathrm{DrPH}$. Dose supplementation with green tea extract improve insulin resistance in obese type 2 diabetes? A randomized, double-blind and placebo-controlled clinical trial. Alternative Medicine Review2011; 16 (2) : 157-63.

14. Hinihger-Favier I, Beneraba R, Coves S, Anderson RA, Roussel AM. Green tea extract decreases oxidative stress and improves insulin sensitivity in an animal model of insulin resistance, the Fructose - Fed Rat, J Am Coll Nutr 2013;28(4): 355-61.

15. Serisier S, Leray V, Poudroux W, Magot T, Ouguerram K, Nguyen P. Effects of green tea on insulin sensitivity, lipid profile and expression of PPARá and PPARã and their target genes in obese dogs $\mathrm{Br} \mathrm{J}$ Nutr 2008;99:1208-16.

16. Senger AEV, Schwanke CHA, Gomez I, Gottlieb MG. Effect of green tea (Camellia sinensis) consumption on the components of metabolic syndrome. J Nutr Health Aging 2012; 16(9): 738-43.

17. Basu A, Sanchez K, Leyva MJ, Wu M, Betts NM, Aston CE, Lyons TJ . Green tea supplementation affects body weight, lipid peroxidation in obese subjects with metabolic syndrome. J Am Coll Nutr 2013; 29(1): 3140 .

18. NECP/ATPIII. Executive Summary of Third Report of the National Cholesterol Education Program (NECP) Expert Panel on Detection, Evaluation, and Treatment of High Blood Cholesterol in Adults (Adult Treatment Panel III). JAMA 2001: 285; 2486-97.

19. Ray KS, Singhania PR. Effect of green tea consumption on selected metabolic biomarkers in Asian Indian women with metabolic syndrome. Food Nutr Sci 2014; 5: 2167-176.

20. Toolsee NA, Aruoma OI, Gunness TK, Kowlessur S, Dambala V, Murad F, Googoolye K, Daus Diana, Indelicato J, Rondeau P, Bourdon E, Bahorun T. Effectiveness of green tea in a randomized human cohort: Relevance to diabetes and its complications.

Volume 15 No. 2 December 2020: 85-90 
Biomed Res Int 2013; 412379: 1-12.

21. Hanhineva K, Torronem R, Bondia-Pons I, Pekkinen J, Kolehmainen M, Mykkanen H, Poutanen K. Impact of dietary polyphenols on carbohydrate metabolism. Int J Mol Sci 2010; 11:1365-402.

22. Ismail NNB, Uthumporm U, Cheng LH, Esa ABM. Effectvof Tea Polyphenols on á-Amylase activity in Starch Hydrolysis. Sains Malaysiana 2018; 47(4): 7319.

23. Kabayashi Y, Suzuki M, Satzu H, Ari S, Hara Y, Suzuki $\mathrm{K}$, Miyamoto Y. Green tea polyphenols inhibit the sodium-dependent glucose transporter of intestinal epithelial cells by a competitive mechanism. J Agr Food Chem 2000; 48(11):5618-23.

24. Kwon O, Eck Peter, Chen Shenglin, Corpe CP, Lee JH. Inhibition of the intestinal glucose transporter GLUT2 by flavonoids. The FASEB J 2007; 21:366-77.

25. Lochocka K, Bajerska J, Glapa A, Winton EF, Nowak JK, Szczapa T, Grebowiec P, L isowska A, Walkowiak J. Green tea extract decreases starch digestion and absorption from a test meal in humans: a randomized, placebo-controlled crossover study. Scientific Reports 2015: 5:12015.

26. Johnston K, Sharp P, Clifford M, Morgan L. Dietary polyphenols decrees glucose uptake by human intestinal Caco-2 cells. FEBS Lett 2005; 579(7): 1653-7.

27. Li T, Liu J, Zhang X, J G. Antidiabetic activity of lipophilic (-)-epigallocatechin-3-gallate derivative under its role of á-glucosidase inhibition. Biomed pharmacother 2007; 61:91-6.

28. Zhong L, Furne JK, Levitt MD. An extract of black, green and mulberry teas causes malabsorption of carbohydrate but not of triacylglycerol in healthy volunteers. Am J Clin Nutr 2006; 84: 551-5.
29. Bjornholm M, Zierath JR. Insulin signal transduction in human skeletal muscle: Identifying the defects in type II diabetes. Biochem Soc trans 2005; 33: 354-7.

30. Cazarolli LH, Zanatta L, Alberton EH, Figueredo MS, Damazio RG, Pizzolatti MG, Silva FR. Flavonoids: Cellular and molecular mechanism of action in glucose homeostasis, Mini review. Med. Chem 2008; 8:1032-8.

31. Uldry M \& Thorens B. The SLC2 family of facilitated hexose and polyol transporters. Pflugers Arch- Eur J Physiol 2004; 447(5):480-9.

32. Han MK. Epigallocatechin gallate, a constituent of green tea, suppresses cytokine-induced pancreatic B -cell damage. Exp Mol Med 2003; 35:136-9

33. Kim Y, Keogh JB, Clifton PM. Polyphenols and glycemic control. Nutrients 2016; 8(1): 17

34. Ortsater H, Grankvist N, Wolfram S, Kuehn N, Sjoholm A. Diet supplementation with green tea extract epigallocatechin gallate prevents progression to glucose intolerance in $\mathrm{db} / \mathrm{db}$ mice. Nutr Metab 2012; 9: 11 .

35. Tachebele B, Abebe M, Birhan W, Addis Z. Health benefit of green tea with emphasis on diabetes mellitus. Am J Food Nutr 2014; 2(5):85-91.

36. Collins FQ, Liu HY, Pi J. Epigallocatechin-3-gallate (EGCG), a green tea polyphenol, suppresses hepatic gluconeogenesis through 5-AMP-activated protein kinase. J Biol Chem 2007; 282: 30143-9.

37. Pilkis SJ \& Claus TH. Hepatic gluconeogenesis/ glycolysis: regulation and structure/function relationships of substate cycle enzymes. Annu Rev Nutr 1991; 11: 465-515.

38. Wolfram S, Raederstorff D, PrellerM, Wang Y, Teixeria SR, Riegger C, Waber P. Epigallocatechin gallate supplementation alleviates diabetes $\mathrm{n}$ rodonts. J Nutr 2006; 136 (10): 2512-8. 